\title{
POSITIVE AND NEGATIVE POLITENESS IN SPOKEN LITHUANIAN
}

\author{
Laura Kamandulytè-Merfeldienè, Sandra Vainilavičiūtè \\ Kaunas Vytautas Magnus University
}

\begin{abstract}
The aim of the research is to discuss the means of expression of positive and negative politeness in prepared and spontaneous spoken language. The research is based on the speech-act theory by Searle (1976) and the theory of positive and negative politeness by Brown and Levinson $(1978,2009)$. The research data are conversations from the Corpus of Spoken Lithuanian, which comprise semi-formal and formal communication in the media, academic discourse, and spontaneous communication in service domains. In total, the research data consist of 144,893 words. The research demonstrates that different politeness strategies are employed in different spoken language registers.
\end{abstract}

Keywords: corpus, expressives, directives, address, Lithuanian

\section{Introduction}

Politeness is a phenomenon inseparable from the communication process, and which is manifested in various forms in every culture. According to Watts (2003: 119), politeness is not restricted to language usage, and several forms of non-linguistic behaviour are also subject to metapragmatic, classificatory, and expressive evaluation as (im)polite. For this reason there are two ways of approaching the study of politeness: 1 . as general conditions on the conventions of social activity types and their interaction orders, or 2. as the forms of linguistic behaviour that are produced in requirement of those conditions. The first approach involves studying what is generally called facework, by looking at the politic behaviour of the social activity type. Some, but by no means all, of the social behaviour we call facework includes linguistic politeness. The second approach 
leads us to classifying a set of linguistic expressions in English as 'polite', i.e. as 'inherently polite'. Most of the linguistic structures used in the negotiation of facework, however, are not usually felt by participants in verbal interaction to be 'polite' (Watts 2003: 119).

Being very multifaceted, politeness can thus be expressed by linguistic and non-linguistic means. Linguistic politeness is considered to be one of the most important parts of the communicative act, which forms the relationship between the addresser and the addressee and often predetermines the success of a conversation to a certain extent. It should be noted that linguistic politeness in interaction may be expressed not only by the usual phrases described in books on linguistic etiquette and guidelines of polite conversations. It may also be a situation-dependent phenomenon where certain phrases which are usually not perceived as markers of linguistic etiquette or politeness obtain such features and demonstrate the friendliness of the speaker (i.e. positive politeness) or an official stance (negative politeness) (Hilbig 2009).

The expression of politeness in Lithuanian is multifaceted and rich. In morphologically-rich Lithuanian, politeness is expressed not only by lexical forms but also by grammatical ones; for instance, when addressing a person politely, the second person plural verb form is used (e.g. ateik-ite:PL:2 cf. ateik-0:SG:2 'Come here'), the subjunctive mood is employed (e.g. Gal gal-ètumèt-e? 'Could you?' cf. Gal gal-it-e? 'Can you'), or diminutives often soften requests (e.g. Ar turi minut-èl-ę? 'Do you have a minute?'; see Dabašinskienè 2009, Dabašinskiene, Voeikova 2015). It should be noted, however, that there is not much research on politeness in the Lithuanian language. While some significant research has already been undertaken in the field of politeness in Lithuanian, compared to other languages (for instance, English), there is a relative lack of research in this field. Still, the amount of research on politeness in Lithuanian has increased in recent years. One of the main pieces of research regarding politeness, which is also the largest in scope, is the monograph by Čepaitienè (2007), in which the author applies the theory of positive 
and negative politeness put forth by Brown and Levinson (2009, first published in 1978). More attention in Lithuania has been devoted to the expression of requests; for example, Hilbig (2009) compared requests in Lithuanian and English, using the Discourse Completion Test. It should be noted that the author proposed a slightly different attitude towards politeness in Lithuania and broadened it by maintaining that politeness is a culturally-specific phenomenon. The expression of politeness in the requests used in internet forums has been analysed by Astrauskiene et al (2014); a comparative study of request formulation in Estonian, Finnish, French, Lithuanian, and Russian was conducted by Pajusalu et al (2017). This research field has also been complemented by Kavaliauskaite (2016) and Ančlauskaitè and Balčiūnienè (2011) who discussed the use of various request types in children's language. Researchers in this area also discuss address forms. For instance, Dobržinskienè (2010) and Girčienè and Kupčinskaitè-Ryklienè (2005) researched the relations between the addresser and the addressee in commercials, Girčienè $(2009,2013)$ examined address forms in TV talk shows, and Gudzinevičiūtè (2013) investigated the expression of 'substantiva cummunia' (nouns which can be used to name a person of masculine and feminine gender. Usually they express negative personal characteristics).

Generalizing, the overview of research on politeness in Lithuania has demonstrated that Lithuanian researchers, more frequently than not, have focused their analysis on a specific language feature. A conclusion may be drawn that there is no considerable research on various details of politeness, taking the holistic approach rather than focusing on a specific linguistic situation, speech act (e.g. directives), or a grammatical component (e.g. address forms); in addition, politeness has been mainly researched in one linguistic domain, such as commercials, TV broadcasts, or internet discourse, without considering all spoken language registers. Therefore, this article attempts to examine the expression of politeness from a broader perspective. The aim of the present research is to discuss the means 
of expression of positive and negative politeness in prepared and spontaneous spoken language. In the present article, politeness is perceived in a broader sense compared to some other Lithuanianlanguage studies, where politeness is defined as etiquette -'the rules of human behaviour which have turned into customs' or 'language formulas which express polite/impolite relations between interlocutors' (Čepaitienè 2007: 11, 68). From the point of view of linguistic pragmatics, politeness is not limited by forms of language etiquette, formulas, rules, and norms. Therefore, in the present article, any linguistic form which expresses respect (negative politeness) or friendliness (positive politeness) in a specific situational context is viewed as an expression of politeness.

The research data are conversations from the Corpus of Spoken Lithuanian ${ }^{1}$, which comprise semi-formal and formal communication in the media (entertainment and informative TV broadcasts), academic discourse (conversations at a university), and spontaneous communication in service domains. In total, the research data consist of 121 conversations and 144,893 words.

The research attempts to analyse positive and negative politeness expressed by pronouns $t u: S G$ 'you' and jūs:PL 'you', singular and plural verbs, address forms, expressives, directives, references to interlocutors, and compliments. The research methods are qualitative and quantitative content analysis and the method of corpus linguistics.

\section{Theoretical considerations}

Various researchers have explained and researched politeness and polite language from various perspectives and have provided different and often contradictory or critical attitudes; however, the most popular theories, which are also considered to be seminal in the field, are those which by Brown and Levinson (2009) and Searle (1976). The present research is based on their works.

\footnotetext{
1 http://sakytinistekstynas.vdu.lt/ (12.06.2018).
} 


\section{I. THE THEORY OF POSITIVE AND NEGATIVE FACE AND POLITENESS}

One of the most significant theories on politeness has been proposed by Brown and Levinson (2009). The authors explained politeness by distinguishing positive and negative face and employing the facesaving theory, where face is also categorized into positive and negative (p. 13).

According to Brown and Levinson, face is a self-image and is presented to other individuals; to be more precise, it may be defined as reputation (ibid.: 59-63). A positive face may be defined as a desire to be respected, appreciated, approved, liked, etc. On the other hand, a negative face refers to the need to be independent and free: a person wants to be independent, free, and undisturbed by others (ibid.: 13, 61-63). Sometimes such linguistic situations are faced in the communication process when positive or negative face is threatened, and these situations are referred to as face-threatening acts (ibid.: 59-60, 65-68). For instance, when a person is criticized, their positive face, i.e. the need to be appreciated and liked, is threatened. When a person is commanded to perform some action, their negative face, i.e. the need to be free to choose the action, is also threatened.

In order to reduce the threats towards positive and negative face, positive and negative politeness strategies may be employed. Positive politeness is manifested by a close relationship with the interlocutor, friendliness, familiarity, warm relationship, acceptance, solidarity, and praise (ibid.). In a communicative act, positive politeness works as a means of developing or fostering a warm, friendly, and close relationship (ibid.: 103, 129-130). Negative politeness is adopted in order to save the addressee's freedom of action, inviolability, and independence, which are the needs of the negative face (ibid.: 13, 61-63). Negative politeness is expressed by maintaining a distance from the addressee, formality, official stance, and respect. 


\subsection{SPEECH-ACT THEORY}

One of the most significant and widely applicable works in the studies on politeness is the speech-act theory by Searle (1976) used in analysing spoken discourse. The classification of speech acts into assertives/representatives, declarations, commisives, expressives, and directives is often used in analysing linguistic politeness in combination with Brown and Levinson's (2009) positive and negative politeness theory. The expression of politeness is probably the most noticeable in requests ascribed to the speech-act group of directives; in addition, expressives are also often identified with the expression and strategies of politeness. Directives and expressives are focused on in the present article; therefore, they are discussed in greater detail below.

Expressives are the speech acts by which the addresser expresses emotions or feelings arising from a certain psychological state preconditioned by certain events in the addresser's reality (Searle 1976). Greetings, farewells, congratulations, excuses, thanksgivings, wishes, curses, etc. are considered to be expressives. Depending on the addresser's linguistic choices, expressives express positive or negative politeness; for instance, in Lithuanian, the expressives sveiki, labas, sveikas 'hi', viso, or iki 'bye' usually are informal and colloquial and express positive politeness, while the expressives laba diena 'good afternoon', labas rytas 'good morning', labas vakaras 'good evening', or viso gero 'good bye' express negative politeness; some expressives, such as ačiū 'thank you' or dékui 'thank you', may be ascribed to both categories.

Directives are speech acts by whose use the addresser wants to affect the addressee in such a way that the latter would take some action and would do or, on the contrary, would not do something (Searle 1976). Speech acts such as requesting, ordering, encouraging, advising, recommending, suggesting, allowing, prohibiting, or questions are considered to be directives. It should be noted that directives may be categorized as either modest (e.g. requests or 
suggestions) or aggressive (e.g. orders or demands), depending on the degree of urgency.

On the basis of directness of these speech acts, request strategies may be categorized into direct, conventionally indirect, and unconventionally indirect (Blum-Kulka, Olshtain 1984). Such requests which are expressed by explicit and performative verbs or the imperative mood are ascribed to the direct strategy (e.g. 'Please close the door'). The conventionally indirect strategy refers to those requests that are indirect and expressed by a question form; in addition, particles are used (e.g. 'Maybe you could close the door?'). The requests which require situational context are ascribed to the unconventionally indirect strategy; in this type of requests, there may be no words indicating a direct request, and hints may be included: 'It's terribly noisy outside' (by which the addresser is requesting for the door to be closed). The direct strategy is ascribed to positive politeness, while the conventionally indirect and unconventionally indirect strategies are seen as negative politeness.

\subsection{SITUATIONAL POLITENESS}

Even though the speech acts discussed above demonstrate politeness per se and express positive or negative politeness, they are not the only way to convey politeness. Linguistic politeness may be transmitted without the utterances ascribed to language etiquette. The phrases which are not categorized as language etiquette and do not indicate any politeness themselves may disclose positive or negative politeness in a certain situation or a certain context (Hilbig 2009). Thus, politeness may not only be constant (e.g. prašom, atidaryk duris 'please, open the door)', but also situation-dependent. For instance, the question 'Have you settled comfortably?' expresses the addresser's concern about the addressee and may be attributed to an expression of positive politeness. Thus, linguistic politeness may be conveyed by various means depending on the situation. As it is 
impossible to describe them all here, the present research focuses on the frequent means of expressing positive and negative politeness with regard to situational politeness: compliments and praise, address forms, and references to the interlocutors. In addition to these means of expression, the present article discusses politeness expressed by the pronouns tu:SG, jūs:PL 'you' and singular/plural verbs. It has to be mentioned that the plural pronoun jūs 'you' may refer to one or several (or even more) people. When the pronoun jus 'you' is used to refer to one person, it demonstrates an official and respectful distance (negative politeness); in addition, in Lithuanian, pronouns may be omitted, and in such a case, politeness is reflected by the second person verb form. We now proceed with a description of the research data and the results of the categories analysed are then provided.

\section{Research data}

The present research employed data from the Corpus of Spoken Lithuanian, which consists of transcribed and grammatically annotated spontaneous informal conversations and more formal public or semi-public speeches from academic and media discourse. The Corpus of Spoken Lithuanian was developed in the framework of national projects coordinated by Vytautas Magnus University (Kaunas, Lithuania) and supported by the Lithuanian State Science and Studies Foundation (grant No. L-12/2008) and by the Research Council of Lithuania (grants No. LIT-9-11). In 2016-2018, the Corpus of Spoken Lithuanian was supplemented by new data due to the implementation of the project 'Contemporary Spoken Lithuanian: A Corpus-based Analysis of Grammar and Lexis' (LIP085/2016) financed by the Research Council of Lithuania under the programme of the State Lithuanian Studies and Dissemination Programme for 2016-2024. The updated corpus consists of 256 conversations (383,587 words) produced by 1,086 speakers ( 659 females and 427 males), whose age ranges from 3 to 81 years. The corpus 
has been compiled using the CHAT transcription format and CLAN programs of the database CHILDES ${ }^{2}$.

The Corpus of Spoken Lithuanian consists of conversations held at various places; they comprise different speaking situations and various roles of social interlocutors. A large part of the conversations in the corpus represent the home domain (spontaneous private communication), and a part of the conversations is recorded on a street, in a village, or in the church. In addition, a substantial part of the conversations is comprised of spontaneous institutional communication, i.e. conversations in the service domain held at an eatery (a restaurant, a cafe, etc.), at a service provider (a grocer's, a newsagent's, a market, a kiosk, a bookshop, a pharmacy, a theatre/ cinema, a bus station ticket office, a beauty salon, a tailor's, a bank, a car service, an insurance company, etc.), a work place, or an office. Public communication conversations comprise academic conversations at universities, universities of applied sciences; there are also conversations recorded at schools or kindergartens. A significant part of the corpus is comprised of TV and radio broadcasts and conversations by telephone (for more information about the corpus, see Kamandulytè-Merfeldienè 2017).

The conversations from the Corpus of Spoken Lithuanian chosen for the present research (121 conversations) represent different language registers; the research thus aims at determining the expression of positive and negative politeness in various situations, ranging from prepared public speeches to spontaneous conversations. The conversations included in the present research comprise academic communication, which is formal, more spontaneous communication in the mass media, and spontaneous institutional communication, i.e. conversations at shops or service providers. In total, the data of the present research consist of 144,893 words; it is described in greater detail in Table 1.

2 https://childes.talkbank.org/ (12.06.2018). 
Table I. The source of the research

\begin{tabular}{|l|c|c|}
\hline & Number of conversations & Number of words \\
\hline Academic speech & 32 & 50192 \\
\hline Speech in mass media & 31 & 56771 \\
\hline Spontaneous institutional speech & 58 & 37930 \\
\hline
\end{tabular}

\section{Results}

\section{I. POSITIVE AND NEGATIVE POLITENESS EXPRESSED BY EXPRESSIVES}

In Lithuanian, expressives may express negative (e.g. laba diena 'good afternoon', viso gero 'good-bye', iki pasimatymo 'see you later', sudie 'God be with you') or positive politeness (e.g. sveiki, labas 'hello', 'hi', ate, viso 'bye'); however, the expressive may be modified in a certain context; for instance, the addition of a name or the informal address form draugeliai 'guys' to the interjection laba diena 'good afternoon' creates positive politeness. The expressives used for thanking ( $a c ̌ i \bar{u}$, dekui 'thank you') are suitable for the expression of both positive and negative politeness. Whether positive or negative politeness is employed in the case of greetings, wishes, etc. may be determined only from the context, and the use of these expressives is related to situational politeness. Thus, in order to determine the expression of positive or negative politeness, context has been analysed in the present research.

The research reveals that the use of expressives is inextricably linked to the language situation and register. For instance, 68 expressives were identified in academic conversations, and their larger part (80\%) mark negative politeness, while only a few expressives are used to express positive politeness (7\%); neutral expressives, which do not convey positive or negative politeness and are mainly employed for thanksgiving, comprise $13 \%$ of all expressives (Figure 1). These results are not surprising as formality is a typical feature of academic communication. In the reports and public speeches analysed, negative politeness is maintained, the listeners are greeted

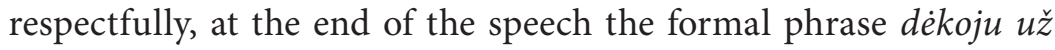


demesi 'thank you for attention' is often added. In the conversations between teachers and students, greetings and farewells are also always formal; there were 5 exceptional instances in teacher's speech when the students were addressed informally by the greeting sveiki 'hi', which indicates willingness to reduce distance and maintain a friendly relationship. It should be noted that there is little variety of expressives in the academic register, and usually traditional expressives for greeting laba diena 'good afternoon' (1) and thanksgiving $a c ̌ i u$, dèkoju 'thank you' are chosen, sometimes intensified by intensifiers labai 'very' or tikrai 'really' in the latter case (2):

(1) Na ka gi, pirmiausia laba diena visiems. 'Well, first good afternoon everyone. ${ }^{3}$

(2) Tikrai ačiū už patarimus, pasiūlymus, taiklias pastabas. 'Really, thank you very much for your pieces of advice, suggestions, and accurate remarks.'

\section{Expressives}

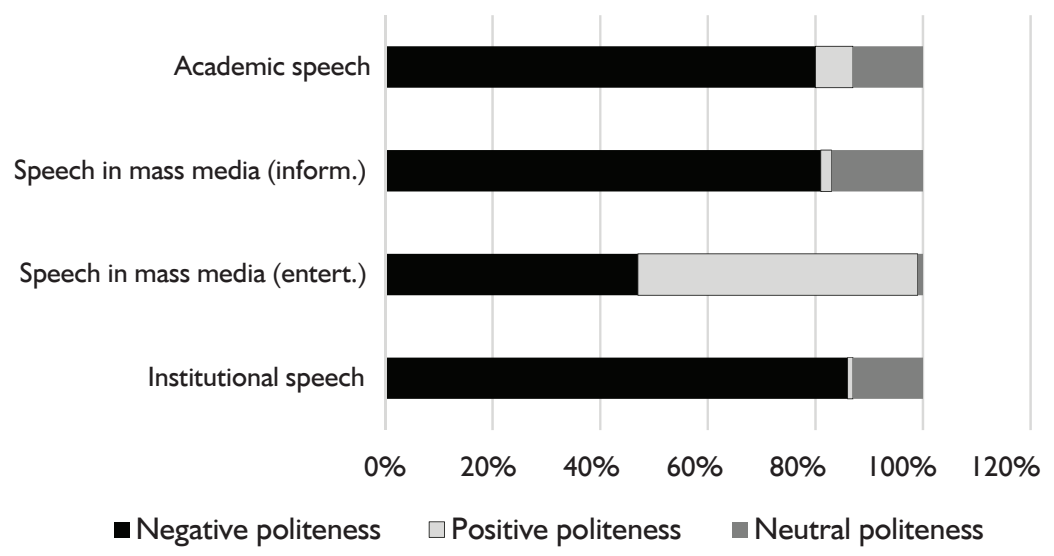

Figure I. Positive, negative, and neutral politeness expressed by expressives

\footnotetext{
3 Here and henceforth the translation is literal in order to retain the actual meaning
} of the directives/expressives and oth. 
In the conversations in the mass media, different tendencies of using expressives were observed. It should be mentioned that all broadcasts in the present investigation are talk shows. News and other broadcasts where the information is read and does not reflect the features of spoken discourse have not been included in the present investigation. Nevertheless, different tendencies of using expressives were observed in informative talk shows and entertainment talk shows. In informative talk shows, where specialists in a certain area are the main participants, the expressives which mark negative politeness are almost always employed (out of 86 expressives, $81 \%$ are negative, $2 \%$ positive, and $17 \%$ neutral; see Figure 1 ). In entertainment talk shows, the expressives which mark positive and negative politeness have been used similarly (out of 98 expressives, $47 \%$ are negative, $52 \%$ positive, and $1 \%$ neutral). In informative broadcasts, where the viewers or the interlocutors are addressed, such greetings as laba diena 'good afternoon' or labas vakaras 'good evening' are typical and a respectful address form is often added, while in entertainment talk shows, the variety of greetings is larger: expressives marking both negative politeness (Laba diena, mieli žiūrovai 'Good afternoon, dear viewers') and positive politeness (Sveiki, vel susirinke prie televizijos ekranu 'Hello to everyone at the TV screens') are employed. It is also important to note that in entertainment talk shows, expressives with the address form which changes politeness are frequently used; for instance, by saying Laba diena, Monika 'Good afternoon, Monika', the host expresses positive politeness, while the phrase Sveiki, gerbiami žiūrovai ' $\mathrm{Hi}$, dear viewers' may be ascribed to negative politeness, but the distance is softened by the informal interjection sveiki ' $h i$ '.

An even wider variety of expressives in informative and entertainment broadcasts was observed in thanksgiving and farewell expressives. Even though the interjections dèkoju, dèkui, or ačiu 'thanks', 'thank you' do not usually mark distance or a close relationship, they express distance when used with respectful address forms, elaborate formulations, or wishes. It may be observed that in 
contrast to greeting expressives, the words which mark thanksgiving or farewell are used in elaborate formulations in almost all instances (3) and are paired with the polite pronoun form $j \bar{u} s$ 'you' or plural verb form (4), thus marking negative politeness (in both, informative and entertainment talk shows). An assumption may therefore be made that when greeting, the hosts sometimes attempt to soften the relationship with the interlocutor and demonstrate a friendly and close connection; however, at the end of the conversation, they express respect and thankfulness, using negative politeness:

(3) Dékoju ir jums, gerbiamieji šeimos gydytojai, už tai, kad esat(e) greta mūsu. 'Thank you, dear family doctors for being with us'.

(4) Tuo tarpu aš dar kartelị dèkoju jums:PL už dèmesị... 'Meanwhile, thank you for your attention'.

The analysis of the institutional register, where spontaneous unprepared communication is typical, has revealed that in the service domain (e.g. shops, cafes, banks, clinics, hairdresser's, etc.) the expressives of negative politeness dominate (86\%). The variety of greeting, farewell, and thanksgiving expressives is not considerable, and the usual greetings and farewells laba diena 'good afternoon', viso gero 'good-bye' or words to express thanks, ačiū, dèkui 'thank you', dominate; in addition, they are typically used without address forms and other additional words. After the formal greeting, a phrase which expresses the purpose frequently follows $(5,6)$ :

(5) Labq diena, du kuponus po penkiolika euru. 'Good afternoon, two coupons for fifteen euros'.

(6) Laba diena, norejau pasiteirauti i Talina rytojaus dienai jūs turite autobusa? 'Good afternoon, I'd like to ask if there is a bus to Tallinn tomorrow'.

Generalizing the use of expressives in prepared and spontaneous communication, one can claim that the expression of politeness is different in different registers of spoken language. In academic and institutional conversations, expressives most frequently mark 
negative politeness and the variety of expressives is not significant, while the expressives in the mass media convey the intentions of the hosts: expressives of negative politeness not only mark a respectful distance but also attempt to please the interlocutor when used with elaborated phrases and additional words. The expressives which mark positive politeness are employed to convey a closer contact with the interlocutor, to establish a friendly relationship, and to encourage the interlocutor when minimizing the distance between them.

\subsection{POSITIVE AND NEGATIVE POLITENESS EXPRESSED BY DIRECTIVES}

The expression of directives is related to social distance, the degree of closeness, and power distance; therefore, a common belief is that the directives which express negative politeness are typical of public speaking. Still, attention should be paid to the fact that in Lithuanian, even direct instructions or commands, which are usually ascribed to positive politeness, may express a respectful relationship with the speaker; for instance, the phrase atidarykite:PL:2 langa '[please] open the window' is used to express positive politeness, but it can be used to address a stranger or a respected person because the second person plural form (atidaryk-ite) of the verb, which is different from the second person singular form (atidaryk-0), implies politeness per se. This has also been revealed by the analysis of spoken language registers. In the academic register, the percentage of direct directives expressing positive and negative politeness is very similar ( $48 \%$ of positive politeness and $52 \%$ of negative politeness; see Figure 2). There is also a considerable number of directives not only in less formal conversations (e.g. dialogues in lectures between the teacher and the students or discussions) (7) but also in presentations or public speeches (8):

(7) Čia iš eiless rašome:PL:1 'Here we're writing in succession.' (The teacher is dictating to the students). 
(8) Pažvelkite:PL:2 $\mathfrak{i}$ šiq lentelę. 'Have a look at this table.'

Interestingly, the directives expressing both positive and negative politeness occur in the same speaker's speech. For example, when talking to students, the teacher gives orders not only directly, but also conventionally indirectly, using particles or questions (9), and unconventionally indirectly, expressing hints or compliments (10):

(9) O nenorèjot(e), kad dar tas šriftas bütų dar didesnis? 'And didn’t you want that font to be larger?'

(10) Viskas pas jus yra gerai, visi tie darbai yra geri, tik jum(s) reikia su šriftu (padirbeti). 'Everything's OK, all those works are good, you only need to work more with the font.'

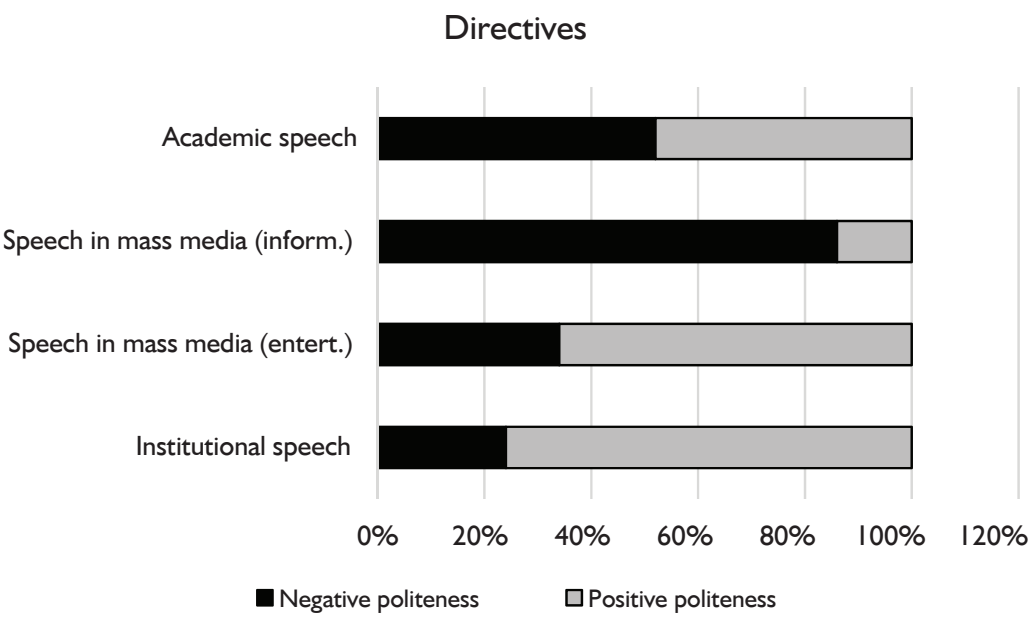

Figure 2. Positive and negative politeness expressed by directives

Similar tendencies can be observed in the media language where the directives expressing both positive and negative politeness are employed. Nevertheless, the categorization of talk shows into more formal informative broadcasts and less formal entertainment broadcasts has revealed significant differences. The research has indicated that the directives expressing negative politeness dominate 
in informative broadcasts and, on the contrary, in entertainment shows, the hosts demonstrate informality and imitate a friendly and close environment, using the directives which express positive politeness. In informative broadcasts, the percentage of indirect directives is $86 \%$ (out of 65 instances), while in entertainment talk shows the figure is 34\% (out of 189 instances; see Figure 2 above). In addition, the degree of insistence is different in entertainment and informative TV talk shows. For instance, in entertainment talk shows, aggressive directives (orders) dominate, and they comprise $61 \%$ of all speech acts used in these broadcasts (11). The remaining $39 \%$ of the directives are direct modest (12) or indirect modest (13). On the contrary, in informative talk shows, the hosts use only modest directives (100\%) (14):

(11) Tai sakyk:IMPER:SG:2 kq nors... 'So, tell something.'

(12) Kviečiu tave, Redita... 'I'm inviting you, Redita.'

(13) O galima paprašyti, pasimatuokit:IMPER:PL:2 ta juostą, kad mes galetume pasigerèti. 'Can I ask you, please try on that sash so that we could also admire it.'

(14) Dar aš noréčiau:COND, kad pasakytumète jūs, daktare profesoriau... 'I'd also like to ask you, doctor professor, to tell us...'

In spontaneous institutional conversations, the speakers use more directives which express positive politeness (76\%). Even though conversations in the service area are businesslike, and the relationship among the interlocutors is not close, in contrast to the expressives described above, directives do not convey social distance, and the speaker just directly and without any etiquette formulas indicates what they wish $(15,16)$ :

(15) Pirkèja: Labą dieną. Šešias vištienos krütinèles kokias didesnes. 'Good afternoon. Six chicken breasts, some bigger ones.'

(16) Negazuoto vandens. 'Still water.' (The buyer comes up to the seller and expresses her wish without any greeting). 
Negative politeness in institutional conversations is usually conveyed by directives with the verb in the subjunctive mood (noréčiau 'I'd like') (17) or the verb in the past tense (norejau 'I wanted'), which corresponds to the polite form noréciau 'I'd like' in these situations (18). It has been observed that the directives expressing negative politeness are used when a greater favour is asked for or when the addressee faces difficulties or problems and they need advice with regard to a specific product or matter:

(17) Laba diena, aš norèčiau pasižiūrèt(i), pasimatuoti, kad būtu mažesnè išmiera šitu mèlynų. 'Good afternoon, I'd like to have a look, to try on, that the size would be the smaller of these blue ones.'

(18) Aš norèjau pasiteirauti dèl tarptautinio pinigu pervedimo, man reiketu pervesti i Suomija privačiam žmogui. 'I wanted to ask about international money transfer, I need to make a transfer to Finland, to a private person.'

Thus, the analysis of institutional conversations has demonstrated that even in public Lithuanian, politeness is often transmitted without any usual etiquette formulas, while directive phrases of positive politeness are frequent even in the case of large social distance or power distance between the interlocutors. In the case of having very clear rights and duties between the interlocutors, the client may express their request directly without any introductions (these are frequently the only words that they pronounce) and the employee may hand over the desired object or provide the service in silence. As it is not considered to be a face-threatening act, neither side frequently uses negative politeness to save the face.

\subsection{POSITIVE AND NEGATIVE POLITENESS EXPRESSED BY PRONOUNS AND THE SECOND-PERSON VERBS}

As has already been mentioned, the plural pronoun $j \bar{u} s$ 'you' may be used to address one or several persons. When it is used to address 
one person, it demonstrates an official and respectful distance (negative politeness); in addition, verbs in the second-person plural form also mark politeness.

The results of the present research have demonstrated that in the spoken language registers, politeness is frequently conveyed by the pronoun jūs 'you' and the verb appears in its second-person plural form. When a person is addressed in academic conversations, the pronoun jūs 'you' or the verb appearing in its second-person plural form is used in $87 \%$ of the instances (19), and in only $13 \%$ of instances (Figure 3 below), the singular pronoun $t u$ 'you' or the second-person singular form has been chosen when addressing an addressee who has less power (20):

(19) Kaip jūs:PL:2 vertinate:PRES:PL:2, kolega? 'How are you evaluating this, colleague?'

(20) Parašyk:IMPER:SG:2 aukščiau dabar. 'Write now above'. (The teacher is addressing the student).

A similar tendency has been observed in the mass media register: $76 \%$ of the pronouns (addressing one person) used by the hosts in entertainment broadcasts and $98 \%$ in informative broadcasts contain the polite form $j \bar{u} s$ or the verb in the second-person plural form, which mark negative politeness. Thus, an assumption may be made that the hosts of both entertainment or informative TV broadcasts tend to strengthen politeness by pronouns, while the verbs in the singular form or the singular pronoun $t u$ ' $y o u$ ', which mark positive politeness, are used only when addressing colleagues or interlocutors with whom they maintain a close relationship or whom they know well.

In institutional conversations, the frequent use of the pronoun $j \bar{u} s$ and verbs appearing in their second-person plural form are also observed, and in this case they comprise $96 \%$. 


\section{Pronoun 'you' and verb 2.pers.}

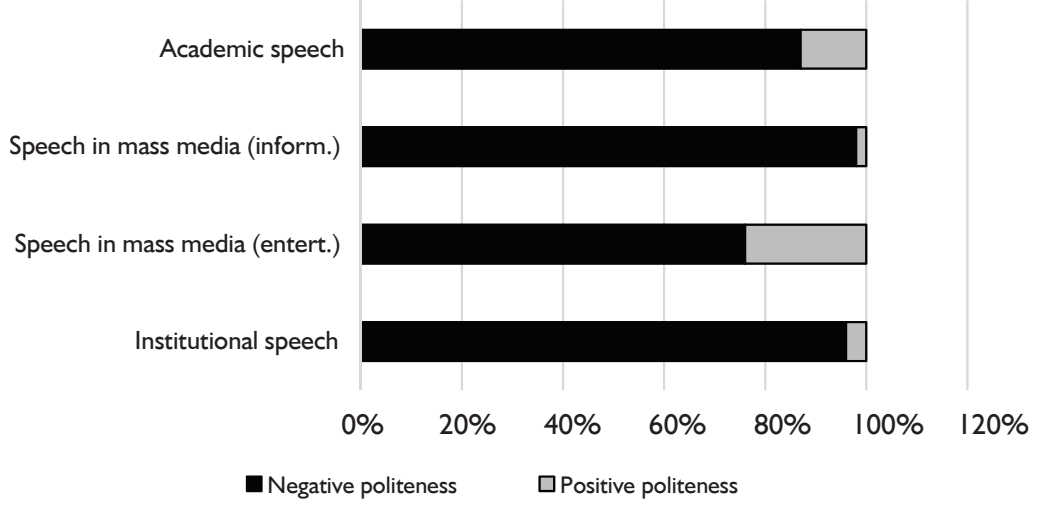

Figure 3. Positive and negative politeness expressed by the pronoun jūs 'you' and plural verb forms

\subsection{SITUATIONAL POLITENESS}

Linguistic politeness may be expressed without utterances ascribed to linguistic etiquette. Such expressions do not mark politeness and may reveal positive or negative politeness only in a certain context. Situational politeness may be expressed by various means; therefore, it is impossible to discuss all of them, analysing such an abundant source for research. This section discusses more frequent means of expressing positive or negative politeness related to situational politeness: address forms, references to interlocutors, and compliments.

Positive and negative politeness expressed by address forms and references to interlocutors. The corpus analysis has revealed that in the academic register, address forms (usually expressed by the vocative) and references to interlocutors (usually expressed by the nominative) mainly mark negative politeness ( $85 \%$ of all 34 address forms and references to interlocutors in this register; see Figure 4 below), which include the position; name and surname; name and surname or another noun with the address form gerbiamasis 'dear'; and the address form typical of public speaking with the word ponas 'Mr.', ponia 'Ms./Mrs.' or the address form kolega 'colleague'. 


\section{Address forms and references to interlocutors}

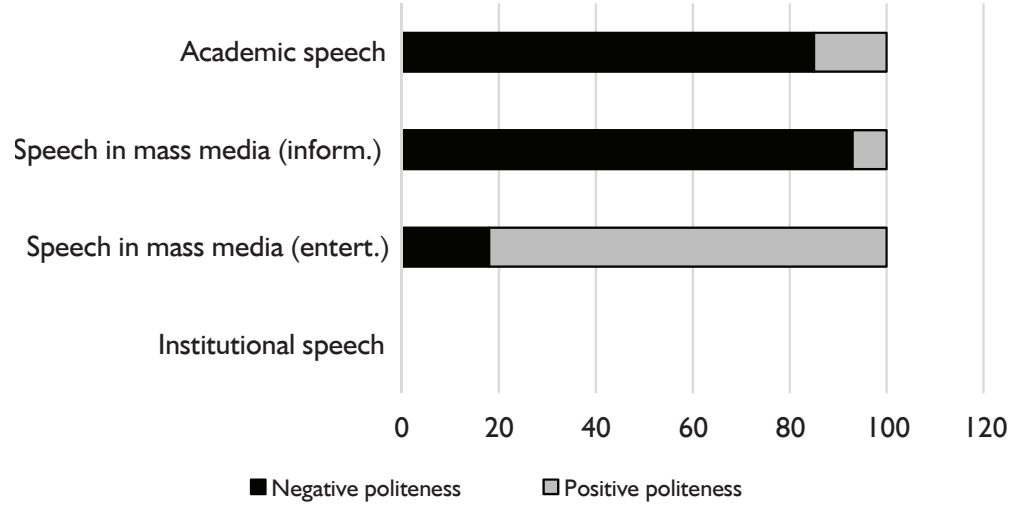

Figure 4. Positive and negative politeness expressed by address forms and references to interlocutors

In the mass media register, the variety of address forms and references to interlocutors is also not considerable. In informative broadcasts, the largest part of the address forms and references is neutral, and positive politeness was almost unobserved, while the address forms which convey negative politeness are mainly the name and surname of the interlocutor, their position (21), or the construction with the adjective gerbiamas (dear) (22) (93\% out of a total of 42 polite address forms and references):

(21) Pirmas klausimas būtų, profesoriau, jums apie <...> sergančius cukriniu diabetu. 'The first question would be to you, Professor, about $<\ldots . . .>$ the people with diabetes'.

(22) Taigi, gerbiamas daktare, jums klausimas yra. 'So, dear doctor, we already have a question for you'.

In entertainment broadcasts, the interlocutors are also mainly addressed neutrally, by their name; however, there are some instances of positive politeness when a diminutive form of the name (23), the nouns merginos 'girls', vaikinai 'boys', the adjectives mieli, mielieji, brangūs 'darling' (24), or the construction mieli mano 'my 
dear' $(82 \%$ out of a total of 69 address forms and references which express politeness) are used.

(23) Miela Ievute:DIM, ar galetum nesijaudinti ir mums viska papasakoti. 'Dear Ievute, could you please be calm and tell us everything.'

(24) Šiandien, mano brangiosios žiūrovès, paruošème jums reportaža apie papuošalus. 'My darling viewers, today we've prepared you a reportage about jewellery.'

The phrases which mark negative politeness, e.g. gerbiamas 'dear' or pone 'mister' + name, are rare in entertainment broadcasts, but they still can be noted (comprising 18\%; see Figure 4 above).

In the institutional register, the references to the interlocutors or address forms were almost unobserved (for this reason, the data of the institutional register are not provided in Figure 4); only a few neutral address forms, such as daktare 'doctor' or the reference by name to an acquaintance working in the institution were noted.

In general, it can be claimed that politeness expressed by address forms or references to the interlocutor depends on the genre or register. In the academic register as well as in informative media language, the address forms and references expressing negative politeness dominate; in entertainment media language, the instances of positive politeness are more frequent, while the politeness expressed by address forms or references to interlocutors is not typical of the institutional register at all.

Positive and negative politeness expressed by compliments and praise. The present research has revealed that compliments and praise are used in all spoken language registers. Figure 5 below demonstrates the frequency of compliments and praise in the registers analysed (compliments and praise mark only positive politeness; therefore, this section does not discuss negative politeness). 


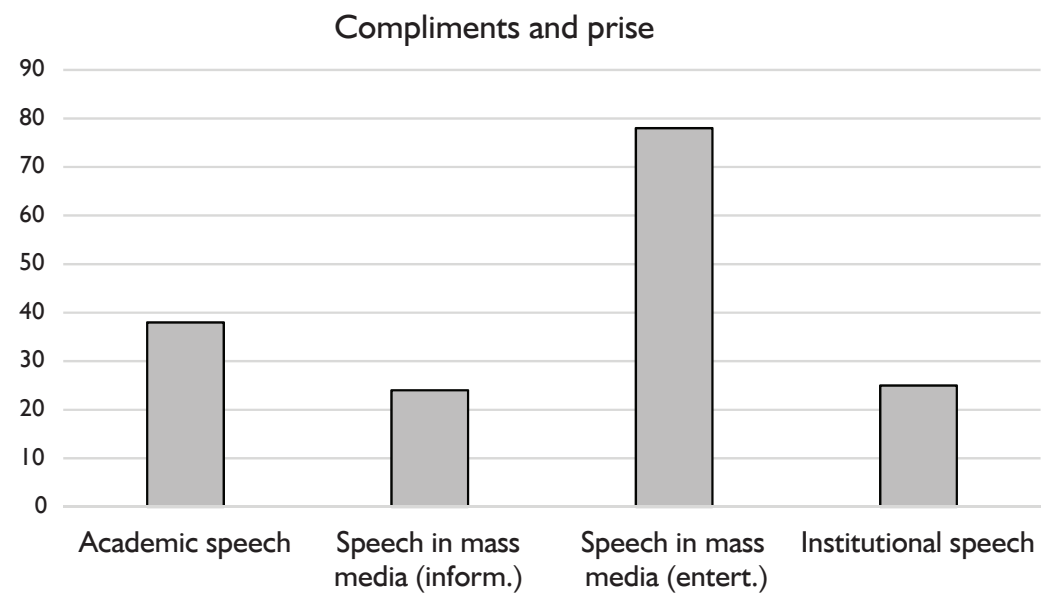

Figure 5. The number of compliments and praise in the registers

The analysis of the academic register (38 instances) revealed that compliments and praise are used to relieve tension in complicated situations; for instance, in academic discourse, compliments are frequently told before remarks $(25,26)$. In addition, certain academic genres are related to the use of praise (as well as of criticism); for example, defences of academic papers, where remarks follow praise.

(25) Puikiai, puikiai tu čia, tik šone dar paštrichuok. 'Great, great, just shade (draw) more on the side.'

(26) Tema yra labai aktuali ir naudinga, tačiau reikètu daugiau demesio skirti praktinio pritaikomumo aprašymui. 'The topic is very topical and useful; however, more attention should be paid to the description of practical application.'

In the mass media discourse, compliments are used to get closer to the interlocutor and to establish a friendly relationship with them. As Figure 5 shows, compliments and praise were much more frequent in the speech of hosts of entertainment broadcasts (i.e. 78 instances in entertainment broadcasts and 20 in informative ones). The results of the present research demonstrate that the hosts of entertainment TV talk shows attempt to create a positive atmosphere and friendliness 
by praising their interlocutors' external qualities and appearance (27), and declaring admiration as concerns their achievements, activities, and skills. In contrast to entertainment broadcasts, in the informative TV talk shows, the hosts do not draw attention to the appearance of their interlocutors. In these broadcasts, the hosts create a friendly relationship by appreciating the profession of the interlocutors and admiring the ideas they express during the broadcast (28):

(27) Dievas jus išvaizda apdovanojo. 'God has given you a great appearance.'

(28) Čia jūs labai gražiai pasakèt(e). 'You've expressed it very nicely.'

The tendency of the hosts to express praise and compliments refer to the strategy of positive politeness formulated by Brown and Levinson (2009: 129), which suggests giving 'presents' to the addressee, i.e. to show that they are liked, valued, and appreciated. In the present research data, in the institutional register, praise and compliments were also observed ( 25 instances), and almost all of them are related to goods or services $(29,30)$ :

(29) Tokios sultingos $<\ldots>$ jos. 'They're so juicy.' (The seller is praising chicken breasts in the meat shop).

(30) Labai faini, juos labai greit(ai), žinokit(e), ir išperka. 'They're really great, you know, they're also bought very quickly.' (The shop assistant is praising the shoes).

In general, one can maintain that positive politeness expressed by compliments and praise in spoken language is used in various situations; nevertheless, it is most frequently employed by professionals, i.e. the hosts of entertainment broadcasts, in order to express appreciation, to maintain positive face, and to fulfil the needs of honour, acceptance, evaluation, and likeability of the interlocutors. 


\section{Conclusions}

The present research has demonstrated that different politeness strategies are employed in different spoken language registers. In academic conversations, the interlocutors create a respectful relationship by using the expressives which express negative politeness, address forms and references to the interlocutor which maintain this distance, and the plural pronoun $j \bar{u} s$ 'you' or the second person plural verb form. It should be noted that a tense situation is often mitigated by orders, compliments, or praise which express positive politeness. In addition, there are more features of positive politeness in less formal academic conversations, such as lectures or discussions; however, they are practically unobserved in presentations or public speeches.

In the media register, two different politeness strategies related to the genre and topic of the conversation, the stance of the host, and the roles of the interlocutors were observed. In the information media, similarly to academic conversations, the means of expressing negative politeness dominate: expressives and directives which mark negative politeness are used, praise and compliments are scarce, and if some of the latter are used, they are directed towards the activities and work of the interlocutors rather than their personalities. In entertainment broadcasts, a respectful relationship with the interlocutor is also maintained, but in this case a less formal and friendlier atmosphere is created; therefore, negative politeness is combined with positive politeness. The expressives of positive and negative politeness are distributed evenly in entertainment broadcasts; besides the directives which express positive politeness being more frequent, the interlocutor is addressed by various address forms which mark positive rather than negative politeness, and the interlocutors are often praised; they are also addressed by the singular form $t u$ 'you', even though the plural form jūs 'you' is more frequent.

In more spontaneous institutional conversations, when speech is unprepared and natural, the directives expressing positive politeness 
are much more typical; little praise is conveyed and address forms or references to interlocutors are not employed at all. The directives of positive politeness in the institutional register may be related to features of Lithuanian culture: when the rights and duties of the interlocutors are clearly defined, interaction is limited to direct and straightforward utterances. Nevertheless, communication etiquette is still obeyed: the expressives which mark negative politeness and the second person plural verb forms are used in these situations.

Generalizing the politeness markers of the Lithuanian language, one can claim that in Lithuanian, the plural pronoun jūs 'you' and expressives are the most closely linked to negative politeness. Directives are comparatively rarely used to express negative politeness direct orders or elliptical object sentences mostly are used; however, respectful distance is often marked by the plural verb form. Address forms are also rare in expressing politeness; nevertheless, there are some constructions with address forms which express negative (gerbiamas pašnekove 'dear interlocutor') or positive politeness (miela kolege 'darling colleague') in various contexts. Compliments and praise always express positive politeness, and they are most often used in the entertainment register in the mass media.

The present investigation has provided some data which could be used by researchers of pragmatics and spoken discourse, and even in the practical activities of various specialists; for instance, when teaching foreigners Lithuanian, more attention should be paid to the directives which express positive politeness (with elliptical object constructions) rather than the directives which express negative politeness with the polite words prašau 'please' and particles. In order to increase the research in this field, researchers could focus on the analysis of politeness in private casual speech, which would facilitate revealing the principles of politeness strategies in different variations of spoken Lithuanian. 


\section{REFERENCES}

Ančlauskaitè, Jolita; Ingrida Balčiūnienė 2011. Nurodymų raiška priešmokyklinio amžiaus vaikų kalboje. - Filologija 16, 5-18.

Astrauskienè, Jurgita; Eglè Brasaitė; Danguolè Satkauskaitė 2014. Sociolingvistinių kintamųjų reikšmė mandagumo raiškai interneto forumuose. - Tarp Eilučių: Lingvistikos, Literatūrologijos, Medijų Erdvè: Tell Me 2013. Mokslinių Straipsnių Rinkinys, 143-156.

Blum-Kulka, Shoshana; Elite Olshtain 1984. Requests and Apologies: A Cross-Cultural Study of Speech Act Realization Patterns (CCSARP). Applied Linguistics 5(3), 196-213.

Brown, Penelope; Stephen C. Levinson 2009. Politeness: Some Universals in Language Usage. Studies in Interactional Sociolinguistics 4. Cambridge: Cambridge University Press.

CHILDES Child Language Data Exchange System https://childes.talkbank. org/ (12.06.2018).

Corpus of Spoken Lithuanian http://sakytinistekstynas.vdu.lt/ (12.06.2018). Čepaitienè, Giedrè 2007. Lietuvių kalbos etiketas: semantika ir pragmatika. Šiauliai: VšI Šiaulių universiteto leidykla.

Dabašinskienė, Ineta 2009. Intimacy, Familiarity and Formality. Diminutives in Modern Lithuanian. - Lituanus 55(1), 65-79.

Dabašinskienė, Ineta; Maria Voeikova 2015. Diminutives in Spoken Lithuanian and Russian: Pragmatic Functions and Structural Properties. Contemporary approaches to Baltic linguistics, 203-234.

Dobržinskienè, Rasa 2010. Adresanto ir adresato santykių raiška televizijos reklamose. - Filologija 15, 14-27.

Girčienè, Jurgita 2009. Daugiskaitinių ir vienaskaitinių kreipimosi formų konkurencija viešojoje sakytineje vartosenoje. - Kalbos kultūra 82, 214-234.

Girčienè, Jurgita 2013. Adresato ịvardijimo raida. - Žmogus kalbos erdvejje 7, 613-621.

Girčienè, Jurgita; Asta Kupčinskaitė-Ryklienė 2005. Kreipimosi ił adresatą būdai reklamoje. - Kalbos kultūra 78, 220-229.

Gudzinevičiūtė, Laima 2013. Kalbinẻ komunikacija: kreipimosi substantiva communia raiška. - Žmogus ir žodis 15(1), 64-70.

Hibling, Inga 2009. Lietuvių ir anglų lingvistinis mandagumas: prašymai (daktaro disertacija). Vilnius: Vilniaus universiteto leidykla. 
Kamandulytè-Merfeldienė, Laura 2017. Sakytinès lietuvių kalbos tekstynas - natūralios vartosenos tyrimų šaltinis. - Taikomoji kalbotyra 9, 176-198.

Kavaliauskaitė, Viktorija 2016. Prašymų raiškos įsisavinimas lietuvių vaikų kalboje. - Taikomoji kalbotyra 8, 160-187.

Pajusalu, Renate; Maret Kaska; Birute Klaas-Lang; Karl Pajusalu; Anu Treikelder; Virve-Anneli Vihman 2017. Characteristics of request formulation in Estonian, Finnish, French, Lithuanian and Russian. - Language Typology and Universals 70(3), 455-488.

Searle, John R. 1976. A classification of illocutionary acts. - Language in Society $5,1-23$.

Watts, Richard J. 2003. Politeness. Key Topics in Sociolinguistics. Cambridge: Cambridge University Press. 
RESÜMEE

\section{POSITIIVSE JA NEGATIIVSE VIISAKUSE VÄLJENDAMINE SUULISES LEEDU KEELES}

Artikli eesmärk on arutleda positiivse ja negatiivse viisakuse väljendamise vahendite kasutamise üle ettevalmistatud ja spontaanses kõnes. Uurimismaterjali moodustavad leedu suulise kõne korpuse lindistatud vestlused, mida on vorrreldud formaalsete ja poolformaalsete meediadialoogide (TV meelelahutus- ja uudistesaated), akadeemiliste vestluste (ülikoolis) ning teeninduses toimuvate spontaansete vestlustega.

Tulemused näitavad, et eri registritesse kuuluvates dialoogides rakendatakse erinevaid viisakusstrateegiaid. Akadeemilistes dialoogides loovad kõnelejad üksteisega arvestava suhte, kasutades keelendeid, mis väljendavad negatiivset viisakust. Sellistes vestlustes kasutatakse erinevaid kõnetlussõnu, kaaskõnelejale viitavaid sõnu ning pronoomenit $j \bar{u} s$ 'sina'. Pingelist situatsiooni on sageli pehmendatud palvete, komplimentide ja tänamistega, mis kõik väljendavad positiivset viisakust.

Uudistesaadetes domineerib sarnaselt akadeemiliste dialoogidega negatiivse viisakuse väljendamine: kasutatakse ekspressiivseid kõneakte ja direktiive, mis väljendavad negatiivset viisakust, tänamine ja komplimendid on harvad. Meelelahutussaadetes hoitakse samuti kaasvestlejaga arvestavat õhkkonda, kuid luuakse sõbralik ja vähem formaalne õhkkond, kasutades nii positiivset kui ka negatiivset viisakust. Positiivse ja negatiivse viisakuse väljendamiseks kasutatavad ekspressiivsed kõneaktid on meelelahutussaadetes jaotunud võrdselt. Positiivset viisakust väljendavad direktiivid on aga sagedasemad ja kaaskõneleja poole pöördutakse pigem positiivset viisakust väljendavate kõnetlussõnadega.

Institutsionaalsetele vestlustele on positiivset viisakust väljendavate direktiivide kasutamine tüüpilisem; vähe leidub tänamist ning 
üldse ei kasutata kaaskõneleja poole pöördumist ja temale viitamist. Ametliku suhtluse positiivset viisakust väljendavad direktiivid on seotud leedu kultuuriga: kui kõnelejate õigused ja kohustused on selgelt kindlaks määratud, on suhtlus piiratud otseste ja otsekoheste lausungitega. Nii või teisiti peetakse aga kinni vestlusetiketist: kasutatakse ekspressiivseid kõneakte, mis väljendavad negatiivset viisakust, ning mitmuse teise pöörde verbivormi. 